\title{
Unintended consequences of using alien fish for human benefit in protected areas
}

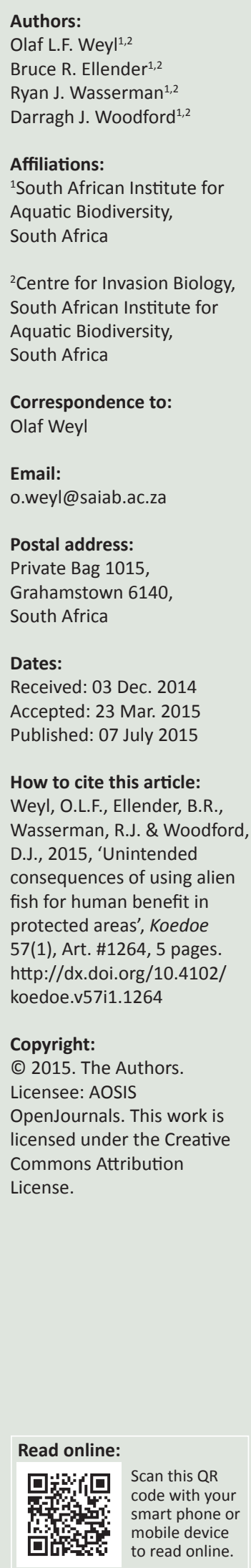

There is increasing pressure on conservation agencies to allow access to natural resources within protected areas for human benefit. Alien fishes are often seen as a convenient resource because their harvest does not conflict with conservation goals. However, allowing such access may have unintended consequences for managers. This opinion essay is intended to provide some insights into how promoting access to alien fish resources can add to the complexity of conservation interventions, may facilitate additional fish introductions and create dependencies on alien fish that could compromise potential eradication efforts.

Conservation implications: Management plans for the utilisation of alien fishes by external stakeholders must include clear exit strategies so that the ability to eradicate when necessary or feasible is not compromised.

\section{Introduction}

By mitigating anthropogenic impacts, protected areas play an important role in the conservation of freshwater biodiversity (Russell 2011). In South Africa, there is increasing pressure for protected areas to sustain themselves economically and provide tangible benefits to bordering communities (e.g. Van Wilgen et al. 2013). For this reason, managers are often faced with the task of developing innovative avenues for increasing revenue and for developing livelihood opportunities for local communities. In South Africa, freshwater fishes are often used to provide such opportunities and there are examples of recreational, subsistence and even commercial fishing in protected areas (e.g. Ellender et al. 2010; McCafferty et al. 2012; Van Wilgen et al. 2013).

Public access to protected areas for angling has a long history, and until the 1980s the production and stocking of fishes to provide angling opportunities was part of the mandate of many provincial conservation authorities (see McCafferty et al. 2012). The tradition of catch and release recreational angling in protected areas is illustrated by the fierce opposition to suggested catch and kill regulations for alien fishes proposed in draft versions of the recently promulgated National Environmental Management: Biodiversity Act (10/2004): Alien and Invasive Species Regulations, 2014 (Republic of South Africa 2014a) and Alien and Invasive Species List, 2014 (Republic of South Africa 2014b). As a result of this opposition, rainbow trout Oncorhynchus mykiss and brown trout Salmo trutta, fishes listed among the world's 100 worst invasive species (Lowe et al. 2000), were excluded from the Alien and Invasive Species List and catch and release angling for other alien and invasive fish species in formal protected areas was specifically included (Republic of South Africa 2014b).

At first glance, alien fish appear to be a convenient resource for public use. After all, alien fishes are generally acknowledged as a major threat to biodiversity both inside and outside of protected areas because they impact on aquatic ecosystems by hybridising with native species, altering habitats, introducing parasites and disease, and by competing with and preying on native biota (Ellender \& Weyl 2014). While their removal from protected areas is thus desirable (Russell 2011), there are, however, several examples where the use of alien fishes in protected areas has resulted in unforeseen and unintended consequences for management. In this opinion essay, we present examples of how promoting access to alien fish resources can add to the complexity of conservation interventions, facilitate additional fish introductions and create dependencies on alien fish that may compromise potential eradication efforts.

\section{Conflicting stakeholder agendas in the Limietberg Nature Reserve, Western Cape}

River fisheries for alien brown trout and rainbow trout in the Western Cape were managed by the Cape Department of Nature Conservation (CDNC) until this role was transferred 
to local angling organisations in the 1980s (Skelton \& Davies 1986). A formal agreement in 1991 gave the Cape Piscatorial Society (CPS) control of trout fishing for five years in several streams in the Limietberg Nature Reserve, which the CPS is still managing even though the formal agreement is now outdated. The Krom River, which flows through the Limietberg Nature Reserve (Figure 1a), is of particular interest at present. The current trout fishery in this river is managed for long-term sustainability by the CPS, who promotes the utilisation of rainbow trout within the reserve by anglers. The provincial conservation agency, CapeNature, benefits through conservation fees generated when anglers book a reach of river to fish through the CPS. The relationship between the conservation authority (CapeNature and its various precursors) and the CPS has historically been positive and co-operative when there was historical legislative protection for trout in the CDNC Ordinance (McCafferty et al. 2012). This protection was removed in the mid-1980s and the current management of the fishery, which includes limiting the number of anglers and enforcing a strict catch and release policy, ensures the long-term presence of rainbow trout (Figure 1b) within the reserve, which would appear to be in conflict with the conservation objectives of protected areas.

A significant conservation threat recently emerged with the discovery of a new species of redfin minnow within the Krom River. The newly described giant redfin Pseudobarbus skeltoni (Figure 1c) has yet to be given an official conservation status, but since it is currently known only from the Krom River and one other stream in the Breede River catchment, evaluation using IUCN Red List criteria is likely to result in a 'critically endangered' status (Chakona \& Swartz 2013).

This discovery places the management of rainbow trout within the Krom River in a new light, as the species is known to deplete or replace populations of redfin minnows (Shelton, Samways \& Day 2015). The presence of rainbow trout within the Limietberg Nature Reserve directly threatens a native fish species (Chakona \& Swartz 2014), and is therefore in conflict with the biodiversity conservation mandate of CapeNature. However, the CPS is considered an important stakeholder for CapeNature and the existence of historical formal management agreements now adds an additional level of complexity to managing the Krom River rainbow trout population. Logically, CapeNature should take steps to reduce the trout population in this protected area to benefit the giant redfin. CapeNature has already successfully embarked on alien fish control projects to better conserve threatened fish species, notably the eradication of alien invasive smallmouth bass Micropterus dolomieu from the Rondegat River (Weyl et al. 2014). However, project proposals by CapeNature to control trout in rivers have met with substantial opposition from trout anglers (Ellender et al. 2014; Marr, Impson \& Tweddle 2012; Weyl et al. 2014). As a result, CapeNature is unable to take decisive conservation action until they have amended the outdated management agreement with the CPS to exclude the Krom
River as a trout water. These negotiations are now underway and it is hoped that a new management agreement with the CPS will be concluded in 2015 (D. Impson [CapeNature] pers. comm., 11 February 2015).

\section{Angler access and illegal alien fish introductions in the Goukamma Nature Reserve, Western Cape}

Illegal introductions of alien fishes for angling are a major problem faced by conservation authorities worldwide (Johnson, Arlinghaus \& Martinez 2009). In South Africa, one such example is the introduction of common carp Cyprinus carpio (Figure 1d) into Groenvlei, a natural lake in the Goukamma Nature Reserve (Figure 1a).

Historically, Groenvlei contained only indigenous estuarine roundherring Gilchristella aestuaria and Cape silverside Atherina breviceps (Phair et al. 2015). As these fishes are too small $(<12 \mathrm{~cm})$ to be of interest to anglers, largemouth bass Micropterus salmoides (Figure 1e) were legally introduced into the lake to develop a fishery in 1934 (De Moor \& Bruton 1988). Subsequently, alien mosquitofish Gambusia affinis were introduced for mosquito control, bluegill Lepomis macrochirus as a forage species for largemouth bass and Mozambique tilapia Oreochromis mossambicus for angling and to reduce algal growth (Coetzee 1980; De Moor \& Bruton 1988). Largemouth bass are a popular target species for recreational anglers while bluegill and Mozambique tilapia are now harvested by subsistence anglers (Weyl, unpublished data).

Common carp were first reported from this lake in the 1990s (Olds et al. 2011). The movement and stocking of common carp has been prohibited in the Western Cape Province since 1947 (McCafferty et al. 2012) and since Groenvlei lacks an inflowing river - thus depending entirely on rainfall, spring flow and seepage for inflow (Parsons 2009) - their presence in the system is a direct result of an illegal introduction. As common carp are a popular angling species in South Africa (Ellender et al. 2014) we contend that the introduction was driven by the intention to develop an additional angling opportunity in the lake.

Recent surveys indicate that the two indigenous fish have co-existed with largemouth bass and other alien fishes for 80 years (Phair et al. 2015; Weyl, unpublished data). The main conservation concern regarding the recent common carp introduction therefore revolves around the potential impact of this fish on water quality - a conservation priority because Groenvlei lacks an outlet and water exits the system mainly by evaporation (Parsons 2009). Common carp have been shown to affect water quality because their bottom grubbing during feeding suspends sediments thus increasing nutrient availability and turbidity (Lougheed, Crosbie \& Chow-Fraser 2009). Carp anglers also often pre-bait areas for carp fishing, a practice that under certain conditions has been shown to contribute substantially to anthropogenic eutrophication (Arlinghaus \& Mehner 2002). For this reason, Goukamma 

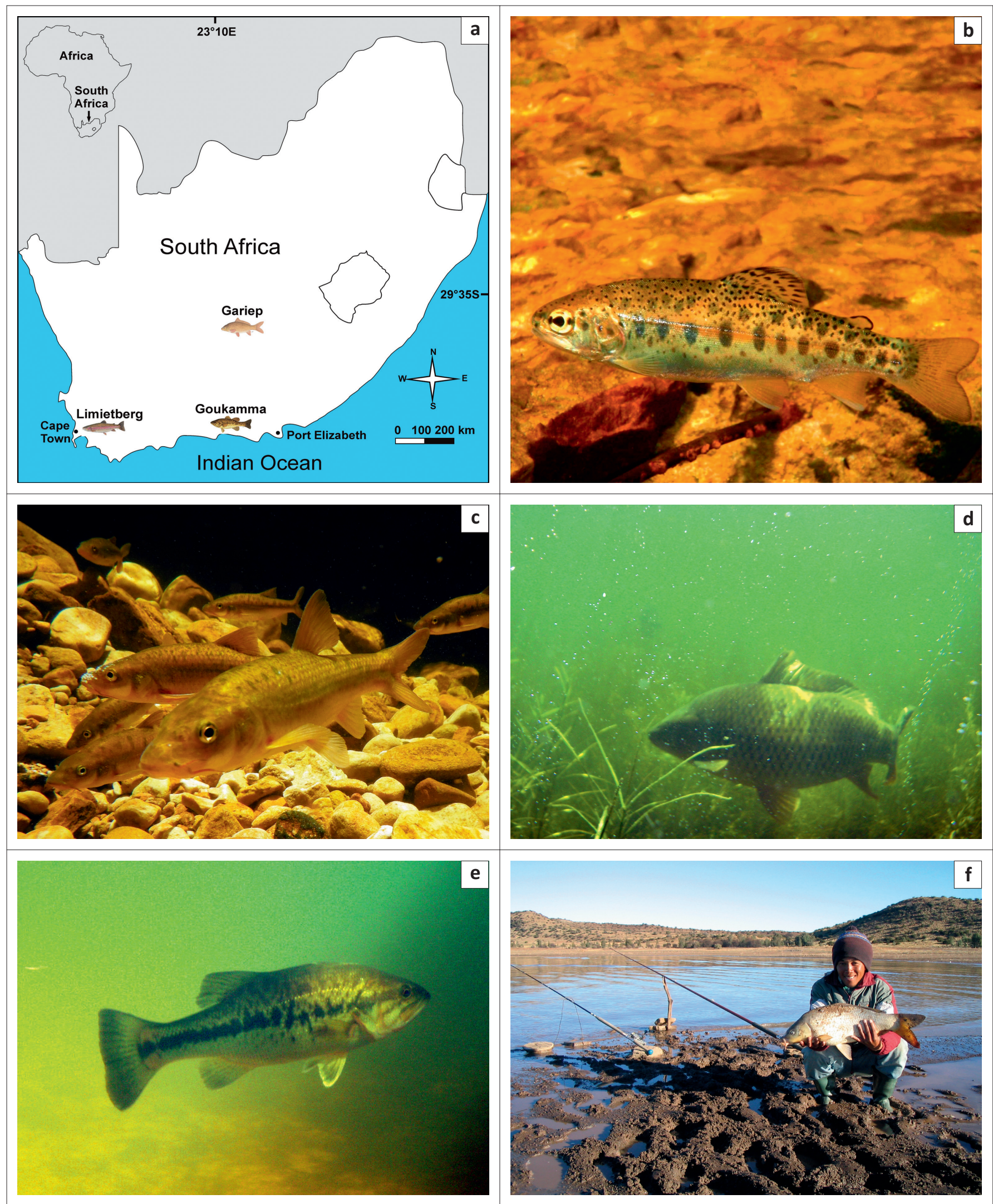

Source: (a) B. Ellender (South African Institute for Aquatic Biodiversity); (b) J. Shelton (Stellenbosch University); (c) R. van der Walt (CapeNature); (d) O. Weyl (South African Institute for Aquatic Biodiversity); (e) D. Woodford (South African Institute for Aquatic Biodiversity) and (f) O. Weyl (South African Institute for Aquatic Biodiversity)

FIGURE 1: (a) Map of South Africa indicating the location of examples of unintended consequences of promoting the use of alien fish. In the Limietberg Nature Reserve, (b) rainbow trout Onchorhynchus mykiss threaten (c) giant redfin minnows Pseudobarbus skeltoni and management interventions are complicated by management agreements between the angling organisations and the conservation agency. In the Goukamma Nature Reserve, the introduction of (d) common carp Cyprinus carpio into Groenvlei was most likely facilitated by the access for angling for introduced fishes such as (e) largemouth bass Micropterus salmoides. (f) One of 450 subsistence anglers whose livelihood depends on access to Lake Gariep via the Oviston Nature Reserve to harvest common carp. Developing similar dependencies elsewhere may negate the ability of reserve managers to eradicate alien fishes. 
management is using gill nets to try to control carp numbers and discourages carp anglers from pre-baiting (Keith Spencer [CapeNature] pers. comm., 17 February 2015).

We contend that in the case of Groenvlei, the introduction of bass and subsequent angler access to this fishery facilitated the introduction of an additional invader which is likely to impact on water quality both directly (through feeding) and indirectly (through ground baiting), resulting in additional management costs.

\section{Creating dependencies may compromise long-term conservation objectives}

It is generally accepted that in the South African context the eradication of alien fishes is only possible in small, relatively isolated environments such as headwater streams (Weyl et al. 2014). Even then, this is an expensive exercise. The removal of alien smallmouth bass from a $4 \mathrm{~km}$ stretch of the lower Rondegat River in the Western Cape, for example, cost ZAR3.3 million (\$290 000) (Impson, Van Wilgen \& Weyl 2013). This situation may be changing, as a result of rapidly evolving technologies for controlling alien fishes over larger spatial scales (Britton, Gozlan \& Copp 2011). Researchers in Australia, for example, are investigating the use of the cyprinid herpes virus-3 (McColl, Cooke \& Sunarto 2014) and genetically modified carp to produce male-only offspring (Thresher et al. 2014) as potential agents to control common carp. This presents somewhat of a conundrum for conservation authorities in South Africa, where poverty eradication, job creation and economic empowerment are national policy objectives, and where alien fishes provide considerable opportunities for food security and economic empowerment, either directly through commercial harvest or indirectly by the provision of equipment and services to recreational anglers (Ellender et al. 2014). On Lake Gariep, for example, some 450 subsistence anglers (Figure 1f) access the Oviston (Eastern Cape) and Gariep (Free State) Nature Reserves (Figure 1a) to harvest common carp, which is an important source of household food security and income (Ellender et al. 2010). This dependency on the fish resource has already resulted in conflicts between fishers and reserve managers regarding access to the lakeshore (Leon Barkhuisen [Department of Economic Development, Tourism and Environmental Affairs, Free State] pers. comm., 17 February 2015) and may result in an inability to eradicate common carp even if it becomes feasible to do so.

\section{Conclusion}

In South Africa, aquatic ecosystems are under pressure from a variety of anthropogenic impacts, including catchment degradation, habitat modification, dewatering, pollution and the introduction of alien fishes (Weyl et al. 2014). Protected areas often offer the last refugia for native biota as many threats are significantly lower here than in surrounding areas. As a result the eradication of alien fishes should be prioritised as this is often the most significant threat in protected areas (Russell 2011). While eradication may not currently be feasible because of the scale of areas affected, managers of protected areas need to be careful when promoting utilisation of alien fishes because this may increase costs of management and compromise long-term conservation objectives. In the Limietberg Nature Reserve, for example, the ultimate removal of trout now requires considerable investment in stakeholder consultations, an essential component in management and insurance against possible reintroductions (Ellender et al. 2014). In Groenvlei, it was access to the lake for anglers that most likely led to the illegal introduction of common carp. This situation is not limited to South Africa. In the Pyrenees, for example, fishing has been banned in lakes protected by national parks as this is the only reliable management policy to avoid new introductions of trout (Miró \& Ventura 2013). Finally, managers of protected areas should take care when developing subsistence and commercial fisheries, as the concomitant social dependencies on alien fish could lead to an inability to eradicate them if it becomes feasible to do so. With regard to aquatic ecosystems, we believe that the needs of biodiversity conservation should generally trump social and economic considerations within protected areas. While this article is not intended to call for a change in the current management practice, we believe that stakeholder agreements regarding the utilisation of alien fishes must include clear exit strategies so that the potential eradication of alien fishes from protected areas is not compromised.

\section{Acknowledgements}

We would like to thank the National Research Foundation of South Africa (NRF, UID: 77444, 86147, 88092) for its ongoing support. Dean Impson (CapeNature), Keith Spencer (CapeNature), Leon Barkhuisen (Department of Economic Development, Tourism and Environmental Affairs) and two anonymous reviewers are thanked for their valuable comments which helped shape this manuscript.

\section{Competing interests}

The authors declare that they have no financial or personal relationships which may have inappropriately influenced them in writing this article.

\section{Authors' contributions}

O.L.F.W. (South African Institute for Aquatic Biodiversity) was the project leader and lead author, B.R.E. (South African Institute for Aquatic Biodiversity), R.J.W. (South African Institute for Aquatic Biodiversity) and D.J.W. (South African Institute for Aquatic Biodiversity) contributed to the study conceptualisation, writing and editing the manuscript.

\section{References}

Arlinghaus, R. \& Mehner, T., 2002, 'Socio-economic characterisation of specialised common carp (Cyprinus carpio L.) anglers in Germany, and implications for inland fisheries management and eutrophication control', Fisheries Research 6, 19-33. http://dx.doi.org/10.1016/S0165-7836(02)00243-6 
Britton, J.R., Gozlan, R.E. \& Copp, G.H., 2011, 'Managing non-native fish in the environment', Fish and Fisheries 12, 256-274. http://dx.doi.org/10.1111/j.14672979.2010.00390.x

Chakona, A. \& Swartz, E.R., 2013, 'A new redfin species, Pseudobarbus skeltoni (Cyprinidae, Teleostei), from the Cape Floristic Region, South Africa', Zootaxa 3686, 565-577. http://dx.doi.org/10.11646/zootaxa.3686.5.5

Coetzee, D.J., 1980, 'Zooplankton and environmental conditions in Groenvlei, southern Cape, during 1976', Journal of the Limnological Society of Southern Africa 6, 5-11. http://dx.doi.org/10.1080/03779688.1980.9633200

De Moor, I. \& Bruton, M., 1988, Atlas of alien and translocated indigenous aquatic animals in southern Africa, South African National Scientific Programmes Report No $144, C S I R$, Pretoria.

Ellender, B.R. \& Weyl, O.L.F., 2014, 'A review of current knowledge, risk and ecological impacts associated with non-native freshwater fish introductions in South Africa', Aquatic Invasions 9, 117-132. http://dx.doi.org/10.3391/ ai.2014.9.2.01

Ellender, B.R., Weyl, O.L.F., Winker, H., Stelzhammer, H. \& Traas, G.R.L., 2010 'Estimating angling effort and participation in a multi-user, inland fishery in South Africa', Fisheries Management and Ecology 17, 19-27. http://dx.doi.org/10.1111/ j.1365-2400.2009.00708.x

Ellender, B.R., Woodford, D.J., Weyl, O.L.F. \& Cowx, I.G., 2014, 'Managing conflicts arising from fisheries enhancements based on non-native fishes in southern Africa', Journal of Fish Biology 85, 1890-1906. http://dx.doi.org/10.1111/ jfb. 12512

Impson, N.D., Van Wilgen, B.W. \& Weyl, O.L.F., 2013, 'Coordinated approaches to rehabilitating a river ecosystem invaded by alien plants and fish', South African
Journal of Science 109(11/12), Art. \#a0041, 4 pages. http://dx.doi.org/10.1590/ sajs.2013/a0041

Johnson, B.M., Arlinghaus, R. \& Martinez, P.J., 2009, 'Are we doing all we can to stem the tide of illegal fish stocking?', Fisheries 34, 389-394. http://dx.doi. org/10.1577/1548-8446-34.8.389

Lougheed, V.L., Crosbie, B. \& Chow-Fraser, P., 1998, 'Predictions on the effect of common carp (Cyprinus carpio) exclusion on water quality, zooplankton, and submergent macrophytes in a Great Lakes wetland', Canadian Journal of Fisheries and Aquatic Sciences 55, 1189-1197. http://dx.doi.org/10.1139/f97-315

Lowe, S., Browne, M., Boudjelas, S. \& De Poorter, M., 2000, '100 of the world's worst invasive alien species: A selection from the global invasive species database', Invasive Species Specialist Group of the World Conservation Union (IUCN), Auckland.

Marr, S.M., Impson, N.D. \& Tweddle, D., 2012, 'An assessment of a proposal to eradicate non-native fish from priority rivers in the Cape Floristic Region, South Africa', African Journal of Aquatic Science 37, 131-142. http://dx.doi.org/10.2989/ 16085914.2012.666654

McCafferty, J.R., Ellender, B.R., Weyl, O.L.F. \& Britz, P.J., 2012, 'The use of wate resources for inland fisheries in South Africa', Water SA 38, 327-344. http:// dx.doi.org/10.4314/wsa.v38i2.18
McColl, K.A., Cooke, B.D. \& Sunarto, A., 2014, 'Viral biocontrol of invasive vertebrates: Lessons from the past applied to cyprinid herpesvirus-3 and carp (Cyprinus carpio) control in Australia', Biological Control 72, 109-117. http://dx.doi.org/10.1016/j. biocontrol.2014.02.014

Miró, A. \& Ventura, M., 2013, 'Historical use, fishing management and lake characteristics explain the presence of non-native trout in Pyrenean lakes: Implications for conservation', Biological Conservation 168, 17-24. http://dx.doi. org/10.1016/j.biocon.2013.07.016

Olds, A.A., Smith, M.K.S., Weyl, O.L.F. \& Russell, I.A., 2011, 'Invasive alien freshwater fishes in the Wilderness Lakes System, a wetland of international importance in the Western Cape Province, South Africa', African Zoology 46, 179-184. http:// dx.doi.org/10.3377/004.046.0109

Parsons, R., 2009, 'Is Groenvlei really fed by groundwater discharged from the Table Mountain Group (TMG) Aquifer?', Water SA 35, 657-662. http://dx.doi. org/10.4314/wsa.v35i5.49425

Phair, N., Barendse, J., Smith, M.K.S. \& Von der Heyden, S., 2015, 'Molecular analyses confirm genetically distinct populations of two indigenous estuarine fish specie in an isolated coastal lake: Implications for the management of introduced ichthyofauna', Conservation Genetics, 05 February. http://dx.doi.org/10.1007/ s10592-015-0701-9

Republic of South Africa, 2014a, National Environmental Management: Biodiversity Act (10/2004): Alien and Invasive Species Regulations, Government Printer, Pretoria.

Republic of South Africa, 2014b, National Environmental Management: Biodiversity Act (10/2004): Alien and Invasive Species List, Government Printer, Pretoria.

Russell, I.A. 2011, 'Conservation status and distribution of freshwater fishes in South African national parks', African Zoology 46, 117-132. http://dx.doi. org/10.3377/004.046.0103

Shelton, J.M., Samways, M.J. \& Day, J.A., 2015, 'Predatory impact of non-native rainbow trout on endemic fish populations in headwater streams in the Cape Floristic Region of South Africa', Biological Invasions 17, 365-379. http://dx.doi. org/10.1007/s10530-014-0735-9

Skelton, P.H. \& Davies, M.T.T., 1986, 'Trout in South Africa', ICHTHOS Special Edition $1,1-20$.

Thresher, R., Van de Kamp, J., Campbell, G., Grewe, P., Canning, M., Barney, M. et al., 2014, Sex-ratio-biasing constructs for the control of invasive lower vertebrates, Nature Biotechnology 32(5), 424-427. http://dx.doi.org/10.1038/nbt.2903

Van Wilgen, N.J., Dopolo, M., Symonds, A., Vermeulen, W., Bester, E., Smith, K. et al., 2013 , 'An inventory of natural resources harvested from national parks in South Africa', Koedoe 55(1), Art. \#1096, 5 pages. http://dx.doi.org/10.4102/koedoe. v55i1.1096

Weyl, O.L.F., Finlayson, B., Impson, N.D., Woodford, D.J. \& Steinkjer, J., 2014, 'Threatened endemic fishes in South Africa's Cape Floristic Region: A new beginning for the Rondegat River', Fisheries 39, 270-279. http://dx.doi.org/ 10.1080/03632415.2014.914924 